\title{
PEMIKIRAN EKONOMI ISLAM IMAM AL-GHAZALI TENTANG KONSEP UANG
}

\author{
Musa $^{1 *}$ Nila $^{2}$ \\ 1IAIN Syaikh Abdurrahman Siddik Bangka Belitung, 2SMAN Olahraga \\ Mohammad Noer
}

mustopamusa349@gmail.com

\begin{abstract}
Al-Ghazali's financial concept shows a distinctive personality, given the inherent philosophical atmosphere as a result of his sufism scholarship. This problem is considered important because it involves basic needs which are the core of all wordly human needs, so that the correct concept is something that all humans must know. This study aims to analyze Imam al-Ghazali's Islamic economic thought about the concept of money. The method in this study is a qualitative literature review. The result of this study are al-Ghazali's financial concept in the perspective of the Islamic economic system, including the prohibition of hoarding money, in the sense that the basic reason for the prohibition of hoarding money is because it will eliminate the functions attached to the money and have a bad impact on the economic system. In addition, the probelm of usury and the sale and purchase of currency, as contained in the word of Allah Swt. that al-Ghazali forbade it. Finally, the evolution of the market, according to al-Ghazali as part of the natural law of everything, is an expression of various desires that arise from oneself to satisfy each other's economic needs.
\end{abstract}

Keywords: Money, Usury, Market Evolution, Islamic Economy

\section{Abstrak}

Konsep keuangan al-Ghazali menunjukkan kepribadian yang khas, mengingat melekatnya suasana filosofis akibat dari keilmuan tasawufnya. Masalah ini dianggap penting karena menyangkut kebutuhan pokok yang merupakan inti dari segala kebutuhan manusia yang sifatnya duniawi, sehingga konsep yang benar adalah sesuatu yang wajib diketahui oleh seluruh manusia. Penelitian ini bertujuan untuk menganalisis pemikiran ekonomi Islam Imam al-Ghazali tentang konsep uang. Metode dalam penelitian ini yakni kualitatif yang bersifat literature review. Adapun hasil dari penelitian ini yakni konsep 
keuangan al-Ghazali dalam perspektif sistem ekonomi Islam diantaranya larangan menimbun uang, dalam artian alasan dasar pelarangan menimbun uang dikarenakan akan menghilangkan fungsi yang melekat pada uang tersebut dan berdampak buruk bagi sistem ekonomi. Selain itu masalah riba dan jual beli mata uang, sebagaimana telah terkandung dalam firman Allah Swt. bahwa al-Ghazali mengharamkan hal tersebut. Terakhir evolusi pasar, menurut al-Ghazali sebagai bagian dari hukum alam atas segala sesuatu, yakni sebuah ekspresi berbagai hasrat yang timbul dari diri sendiri untuk saling memuaskan kebutuhan ekonomi.

Kata Kunci: Uang, Riba, Evolusi Pasar, Ekonomi Islam

\section{A. Pendahuluan}

Awalnya setiap orang berusaha mendapatkan keperluannya dengan cara sendiri yakni berburu, membuat pakaian sendiri dari bahan-bahan yang sederhana serta mencari buah-buahan untuk dikonsumsi sendiri. ${ }^{1}$ Hal ini dikarenakan masih sederhana dan belum membutuhkan satu sama lainnya. Dengan kata lain, dikenal sebagai zaman sebelum tukar menukar yakni setiap orang belum mengenal kegiatan jual beli. ${ }^{2}$

Saat ini telah berbeda, setiap orang yang hidup di dunia ini tidak lepas dari aktivitas jual beli dan ditunjang oleh uang serta tidak ada orang yang tidak memanfaatkan suatu yang dianggap penting untuk kehidupannya yakni uang. Sebaliknya, jika ada yang memanfaatkan uang pada masa tersebut maka sistem ekonomi akan lumpuh dan tidak berkembang sebagaimana yang diharapkan. ${ }^{3}$ Uang selalu menjadi tranding topik yang dibicarakan dalam kajian ekonomi Islam, karena sebagai nadi perekonomian. Tanpa uang sistem ekonomi tidak berjalan dengan baik. Sekarang ini, sebagian besar aktivitas ekonomi sangat diharapakan baik di Indonesia

\footnotetext{
${ }^{1}$ Etty Puji Lestari, Ekonomi Moneter, (Tangerang Selatan: Universitas Terbuka, 2019), hlm. 1.5 .

${ }^{2}$ Mustafa Edwin Nasution, dkk, Pengenalan Eksklusif Islam, (Jakarta: Kencana, 2007), hlm. 29.

${ }^{3}$ Rimsky K. Judisseno, Sistem Moneter dan Perbankan di Indonesia, (Jakarta: Gramedia Pustaka, 2005), hlm. 1.
} 
maupun di negara lainnya, baik pada aktivitas produksi, distribusi, konsumsi, atau gambaran dari modal. ${ }^{4}$

Al-Maqrizi menjelaskan bahsawanya mata uang memiliki fungsi yang menentukan aktivitas manusia karena dengan adanya uang, manusia bisa mencukupi kebutuhan hidup dan memperlancar aktivitas sosialnya. Selanjutnya apabila dilihat dari segi hukum, logika, dan tradisi bentuk mata uang itu diterima sebagai standar nilai yakni adanya emas dan perak. Oleh sebab itu, mata uang yang bahannya tidak berasal dari kedua logam tersebut maka tidak layak disebut mata uang. ${ }^{5}$

Ghufran A. Mas'adi mengatakan bahwasanya fungsi uang yakni sebagai media barter dan bisa dianggap oleh setiap orang. Penerimaan fungsi tersebut dipandang bisa memberikan dampak buruk atau tidak adil saat terjadi transaksi tukar menukar. Saat ini, bidang industri dan perdagangan menyatakan fungsi uang tidak semata-mata disahkan sebagai alat tukar, namun juga disahkan sebagai alat dagangan dan kekayaan. Dilihat dari fungsinya sebagai dagangan, uang memiliki kedudukan yang serupa dengan barang yang bisa dijadikan dalam bertransaksi untuk memperoleh keuntungan. Selanjutnya dilihat dari fungsinya sebagai kekayaan, dengan adanya uang bisa memperoleh hal yang diperlukan baik dalam bentuk barnag maupun jasa. ${ }^{6}$

Salah satu tokoh Islam yang produktif mengkaji ekonomi mikro dan fungsi uang ialah Imam al-Ghazali. Pada kajiannya banyak menyentuh masalah-masalah yang dianggap berhubungan dengan uang, fungsi, dan evolusi penggunaannya. Beliau menjelaskan bahwa uang adalah karunia Allah yang dimanfaatkan manusia sebagai penghubung atau alat untuk

\footnotetext{
${ }^{4}$ Rina Rosia, Pemikiran Imam Al-Ghazali Tentang Uang, Jurnal Ilmiah Ekonomi Islam, vol. 4, no. 1 (2018), hlm. 14-27.

5 Adiwarman A. Karim, Sejarah Pemikiran Ekonomi Islam, (Jakarta: Rajawali Press, 2004), hlm. 420 . 15.
} 
memperoleh beragam kebutuhannya yang secara materiil tidak mempunyai nilai apa-apa, namun lebih diperlukan setiap orang dalam usaha pemuasannya. Selain itu, menurut beliau tujuan uang yakni untuk mengukur seluruh kekayaan yang hendak diperjualbelikan. ${ }^{7}$

Konsep keuangan al-Ghazali menunjukkan kepribadian yang khas, mengingat melekatnya suasana filosofis akibat dari keilmuan tasawufnya. Akan tetapi, yang menarik dari persepsi keuangannya yakni tidak terlibat pada aturan pemikiran saja, tetapi penggabungan antara keadaan nyata atau yang terjadi sebenarnya dan pemikiran yang disertai dengan alasan yang rasional dan transparan. Al-Ghazali adalah salah satu filsuf Islam yang sangat kaya akan karya-karyanya. Hasil karyanya bukan hanya masalah ekonomi saja, namun mencakup berbagai bidang keilmuan. Kitabnya merupakan hasil penggabungan dari berbagai bidang keilmuan yang ditulis oleh Imam alGhazali baik materiil maupun religius dan kecerdasan. ${ }^{8}$

Konsep keuangannya sangat unik karena mengandung ilmu tasawuf dan didalamnya memiliki pengaruh yang baik. Konsep inilah kemudian dicatat pada bab al-Syukru dalam kitab monumentalnya, yakni kitab Ihya al'Ulumuddin. Keunikan dan ciri khas pemikirannya tentang uang sangat menarik untuk dibahas, sebab beliau dikenal sebagai potret di lingkungan umat Islam yakni salah satu tokoh ilmu tasawuf dan filsafat. Bahkan beliau dikenal sebagai ulama sufi tradisional sehingga kehidupan dan pemikirannya lebih mengarah pada akhirat saja, serta jauh dari kegiatan duniawi. Pandangan tersebut tidak semuanya benar jika dipahami dari berbagai karya tulisnya yang cukup kaya akan pengetahuan dari berbagai keilmuan baik ekonomi maupun lainnya.

Untuk memperluas penelitian ini, maka peneliti mengumpulkan

\footnotetext{
7 Jalaluddin, Konsep Uang Menurut Al-Ghazali, Asy-Syari'ah, vol. 16, no. 2 (2014), hlm. $169-78$.

8 Ahmad Dimyati, Teori Keuangan Islam Rekontruksi Metodologis Terhadap Teori Kauangan Al-Ghazali, (Yogyakarta: UII Press, 2008), hlm. 50.
} 
berbagai karya-karya peneliti sebelumnya mengenai pemikiran Al-Ghazali diantara penelitian yang dilakukan oleh Sutopo ${ }^{9}$, menjelaskan bahwa ekonomi menurut Imam Al-Ghazali dapat dikelompokkan sebagai berikut yakni perubahan dan kemajuan tempat jual beli, produksi, tukar menukar dan kemajuan uang, serta kontribusi suatu negara dan keuangan umum. Selain itu, Rina Rosia ${ }^{10}$ juga menjelaskan bahwasanya fungsi uang itu ada dua yakni sebagai perantara perubahan (pertukaran) dan satuan hitung. Dengan demikian, menurut syariah tujuan permintaan uang itu untuk motif kehatihatian dan motif transaksi. Namun berbeda pada konvensional yakni sebagai perantara untuk menyimpan harta kekayaan pada motif spekulatif. Perihal yang sama, penelitian yang dilakukan oleh Soritua Ahmad Ramdani Harahap ${ }^{11}$, menjelaskan bahwasanya fungsi uang sebagai satuan hitung dan media aktivitas bukan dagangan. Dengan demikian menurut Islam, kegiatan memendamkan harta kekayaan dan menyelewengkan tidak dianjurkan terutama dalam fungsi uang itu sendiri.

Penelitian yang dilakukan sekarang berfokus pada masalah pemikiran Imam Al-Ghazali terkait keuangan dalam perspektif ekonomi Islam. Perihal itu penting untuk diteliti karena berhubungan dengan kebutuhan pokok yang merupakan esensi dari seluruh kebutuhan setiap orang yang sifatnya duniawi bukan akhirat, sehingga konsep yang akurat adalah sesuatu yang wajib diketahui oleh seluruh manusia. Jadi penelitian tersebut berjudul Pemikiran Ekonomi Islam Imam Al-Ghazali Tentang Konsep Uang.

9 Sutopo, Pemikiran Imam Ghazali Tentang Ekonomi, Jurnal Ummul Qura, vol. 3, no. 2 (2013), hlm. 49-58.

${ }^{10}$ Rina Rosia, Pemikiran Imam Al-Ghazali Tentang Uang, Jurnal Ilmiah Ekonomi Islam, vol. 4, no. 1 (2018), hlm. 14-27.

11 Soritua Ahmad Ramdani Harahap, Pemikiran Imam Al-Ghazali Tentang Fungsi Uang, Jurnal Laa Maisyir, vol. 6, no. 1 (2019), hlm. 1-15. 


\section{B. Pembahasan}

\section{Pemikiran Ekonomi Al-Ghazali}

Al-Ghazali banyak dikenal masyarakat yang memiliki berbagai keilmuan, salah satunya bidang ekonomi. Pemikiran beliau tentang ekonomi sering kita lihat dalam tulisan monumentalnya Ihya al-'Ulumuddin. Dalam analisisnya mengenai ekonomi meliputi uang, perdagangan, pembagian tenaga kerja, perilaku komsumsi, dan organisasi masyarakat dalam perekonomian. Kemudian kebutuhan pokok termasuk pada furniture, peralatan pernikahan, alat-alat yang dipakai dalam rumah tangga, dan aset lainnya. Beliau juga memperluas ekonomi Islam dengan pokok pembagian kerja dan teori perubahan uang. Di samping itu, beliau mengkritik masalah penimbunan uang di bawah lantai atau bantal, karena uang itu diciptakan untuk memudahkan transaksi jual beli dan masalah lainnya.

Sebagai tokoh ahli suluk, al-Ghazali banyak memberikan dedikasi ilmu ekonomi dalam hal keagamaan dan akhlak. Pada tulisan monumentalnya, beliau sudah membahas defisit dari sistem tukar menukar barang dan yang lebih pentingnya uang itu sebagai alat tukar dan pengukur nilai barang maupun jasa. Beliau menyamakan uang sebagai cermin, artinya cermin tidak memiliki warna tetapi bisa menggambarkan segala warna. Dengan demikian, uang tidak memiliki harga tetapi bisa menggambarkan segala harga. Uang itu tidak dapat diperjualbelikan, ketika memperjualbelikan uang sama dengan memberikan dampak buruk pada ekonomi, karena akan menurunkan jumlah uang yang berfungsi sebagai alat tukar. Uang bisa saja tidak terbuat dari emas dan perak, misalnya uang kertas, namun negara wajib menerangkannya sebagai alat pembayaran yang sah. Beliau mengungkapkan bahwasanya menggandakan uang merupakan hal yang dianggap serius dalam dunia ekonomi karena dampaknya berkelanjutan, bahkan lebih serius atau berbahaya dari pencurian uang. 


\section{Konsep Uang}

Al-Ghazali mengungkapkan bahwasanya uang mengatasi permasalahan yang terjadi pada pertukaran barter. Beliau juga mendiskusikan dampak buruk dari pengganda penurunan nilai mata uang, penelitian yang dilakukan pada beberapa dekade, selanjutnya penelitian ini juga di ungkapkan Nicholas Oresme, Thomas Gresham, dan Richard Cantillon. Pada tulisan monumentalnya, beliau mengartikan uang sebagai barang yang berfungsi sebagai media untuk memperoleh barang lain. Barang tersebut dipandang tidak memiliki nilai. Oleh sebab itu, beliau menyamakan uang sebagai cermin yang tidak memiliki warna sendiri tapi bisa menggambarkan segala warna.

Mengacu pada standar tersebut, beliau tidak semata-mata mementingkan pada aspek fungsi uang. Penjelasan yang demikian lebih sempurna dibandingkan penjelasan-penjelasan yang disampaikan oleh ekonom konvensional, karena lebih mengedepankan uang sekedar fungsi yang melekat pada uang itu sendiri. Oleh sebab itu, beliau mengartikan uang itu hanya sebagai standar harga barang atau benda maka uang tidak mempunyai nilai intrinsik yang dianggap tidak pernah ada. Beliau mengungkapkan uang tidak mempunyai nilai intrinsik terkait permintaan terhadap uang, riba, dan jual beli mata uang.

Konsep keuangan al-Ghazali menunjukkan kepribadian yang khas, mengingat melekatnya suasana filosofis akibat dari keilmuan tasawufnya. Akan tetapi, yang menarik dari persepsi keuangannya yakni tidak terlibat pada aturan pemikiran saja, tetapi penggabungan antara keadaan nyata atau yang terjadi sebenarnya dan pemikiran yang disertai dengan alasan yang rasional dan transparan

Pada tahun 1993, Bernand Lewis mengemukakan konsep keuangan alGhazali menunjukkan kepribadian yang khas, mengingat melekatnya suasana filosofis akibat dari keilmuan tasawufnya. Akan tetapi, yang menarik dari 
persepsi keuangannya yakni tidak terlibat pada aturan pemikiran saja, tetapi penggabungan antara keadaan nyata atau yang terjadi sebenarnya dan pemikiran yang disertai dengan alasan yang rasional dan transparan. ${ }^{12}$ Oleh sebab itu, agar pemikiran keuangannya tersusun rapi maka diperlukan konsep yang lebih baik lagi. Berikut filosofis keuangan al-Ghazali dalam perspektif ekonomi Islam.

\section{a. Larangan menimbun uang}

Dilihat dari konsep Islam uang merupakan suatu benda yang dianggap penting atau memiliki dampak pada sistem perekonomian masyarakat. Oleh sebab itu, ketika uang diambil dari penyalurannya, maka fungsi penting dari uang tersebut akan hilang. Untuk itu, praktik menimbun uang dalam Islam dilarang keras karena akan memberikan dampak pada ketidakstabilan perekonomian masyarakat. Alasan utama pelarangan menimbun uang yakni akan mengabaikan fungsi yang melekat pada uang itu. Adapun tujuan diciptakan uang yakni sebagai media transaksi sehingga uang menyebar ke masyarakat dan bukan dikuasai oleh suatu kelompok tertentu.

Adapun menurut teori ekonomi bahwasanya jumlah uang yang beredar dengan jumlah barang yang ada mempunyai ikatan yang erat sekaligus berbanding terbalik. Apabila jumlah uang beredar melampaui jumlah barang yang ada maka terjadi inflasi. Demikian juga sebaliknya, apabila jumlah uang yang beredar tidak melampaui dari barang yang ada maka terjadi deflasi. Jadi, keduanya penyakit ekonomi yang mesti dihindari dan diatasi dengan jumlah uang yang beredar dengan jumlah barang yang ada selalu seimbang. ${ }^{13}$

\section{b. Permasalahan riba}

Riba merupakan tambahan atas modal pokok yang didapatkan

${ }^{12}$ Nur Chamid, Jejak Langkah Sejarah Pemikiran Ekonomi Islam, (Yogyakarta: Pustaka Pelajar, 2017), hlm. 220-222.

${ }_{13}$ Adiwarman Azwar Karim, Ekonomi Islam: Suatu Kajian Ekonomi Makro, (Jakarta: Karim Business Cansulting, 2001), hlm. 6. 
dengan sistem yang salah. Secara spesifik larangan riba terdapat beberapa firman Allah Swt. sebagai berikut:

1) Surah al-Baqarah ayat 275

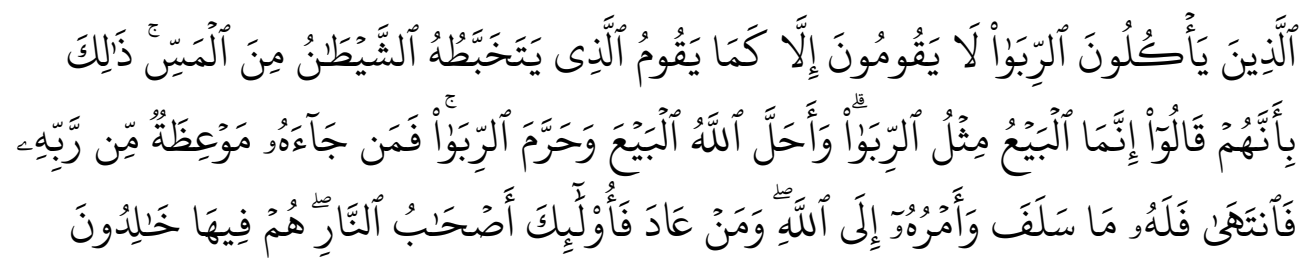

"Orang-orang yang makan (mengambil) riba"14 tidak dapat berdiri melainkan seperti berdirinya orang yang kemasukan syaitan lantaran (tekanan) penyakit gila. ${ }^{15}$ Keadaan mereka yang demikian itu, adalah disebabkan mereka berkata (berpendapat), sesungguhnya jual beli itu sama dengan riba, Padahal Allah telah menghalalkan jual beli dan mengharamkan riba. Orang-orang yang telah sampai kepadanya larangan dari Tuhannya, lalu terus berhenti (dari mengambil riba), maka baginya apa yang telah diambilnya dahulu 16 (sebelum datang larangan); dan urusannya (terserah) kepada Allah. Orang yang kembali (mengambil riba), maka orang itu adalah penghuni-penghuni neraka; mereka kekal di dalamnya".

2) Surah al-Baqarah ayat $278-279$

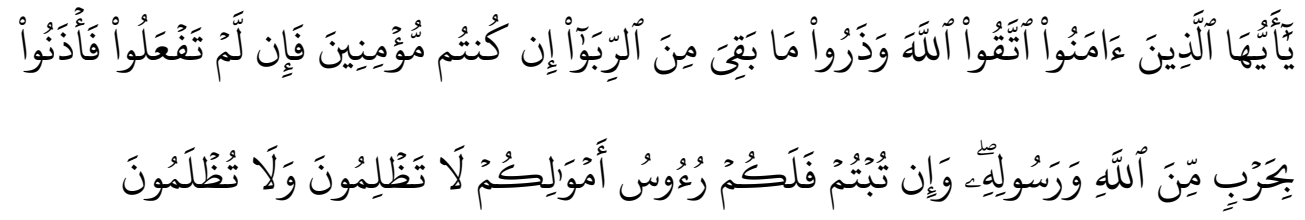

"Hai orang-orang yang beriman, bertakwalah kepada Allah dan tinggalkan sisa riba (yang belum dipungut) jika kamu orang-orang yang beriman. Maka jika kamu tidak mengerjakan (meninggalkan sisa riba), maka ketahuilah,

14 Riba itu ada dua macam: nasiah dan fadhl. Riba nasiah ialah pembayaran lebih yang disyaratkan oleh orang yang meminjamkan. Riba fadhl ialah penukaran suatu barang dengan barang yang sejenis, tetapi lebih banyak jumlahnya karena orang yang menukarkan mensyaratkan demikian, seperti penukaran emas dengan emas, padi dengan padi, dan sebagainya. Riba yang dimaksud dalam ayat ini riba nasiah yang berlipat ganda yang umum terjadi dalam masyarakat Arab zaman jahiliyah.

${ }^{15}$ Maksudnya: orang yang mengambil riba tidak tenteram jiwanya seperti orang kemasukan syaitan.

${ }^{16}$ Riba yang sudah diambil (dipungut) sebelum turun ayat ini, boleh tidak dikembalikan. 
bahwa Allah dan Rasul-Nya akan memerangimu. dan jika kamu bertaubat (dari pengambilan riba), maka bagimu pokok hartamu; kamu tidak menganiaya dan tidak (pula) dianiaya".

3) Surah ar-Rum ayat 39

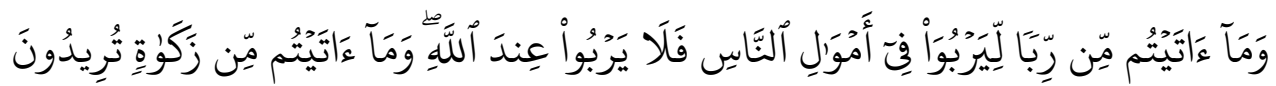

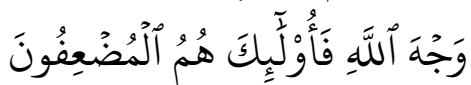

"Dan sesuatu riba (tambahan) yang kamu berikan agar dia bertambah pada harta manusia, maka riba itu tidak menambah pada sisi Allah. dan apa yang kamu berikan berupa zakat yang kamu maksudkan untuk mencapai keridhaan Allah, maka (yang berbuat demikian) itulah orang-orang yang melipat gandakan (pahalanya)".

4) Surah an-Nisa' ayat 160-161
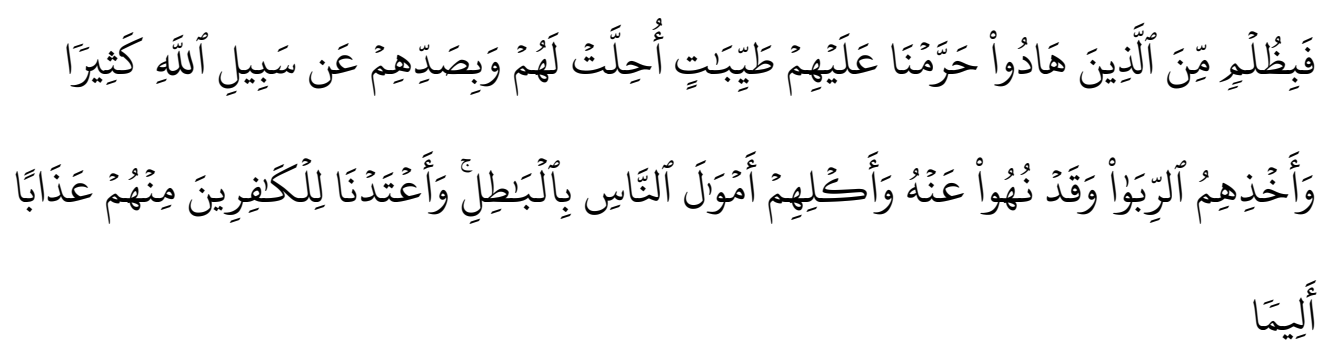

"Maka disebabkan kezaliman orang-orang Yahudi, kami haramkan atas (memakan makanan) yang baik-baik (yang dahulunya) dihalalkan bagi mereka, dan karena mereka banyak menghalangi (manusia) dari jalan Allah, dan disebabkan mereka memakan riba, padahal Sesungguhnya mereka telah dilarang daripadanya, dan karena mereka memakan harta benda orang dengan jalan yang batil. Kami telah menyediakan untuk orang-orang yang kafir di antara mereka itu siksa yang pedih".

5) Surah ali Imran ayat 130

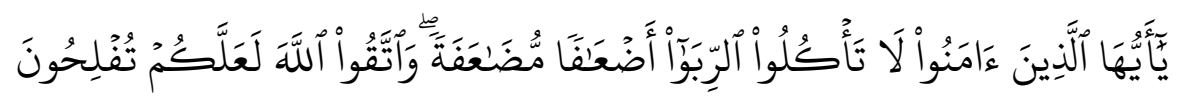

"Hai orang-orang yang beriman, janganlah kamu memakan riba dengan 
berlipat ganda17 dan bertakwalah kamu kepada Allah supaya kamu mendapat keberuntungan".

Alasan esensial beliau melarang riba yakni motif diciptakan uang itu sendiri, sehingga berfungsi sebagai alat tukar dan standar nilai barang saja, bukan sebagai dagangan. Perbuatan riba dengan cara tukar menukar yang serupa adalah perbuatan yang keluar dari tujuan awal penciptaan uang dan dilarang oleh agama. ${ }^{18}$ Selain itu, al-Ghazali juga menganalisis transaksi non moneter yang mana bunga mungkin masih terjadi tetapi dalam bentuk terselubung. Ada dua kemungkinan bunga bisa muncul dalam bentuk terselubung. Salah satunya terkait dengan penukaran emas dengan emas, perak dengan perak, gandum dengan gandum, dan lain-lain. Namun terdapat perbedaan dalam jumlah angka atau saat pengiriman. Ketika pengiriman tidak langsung dan kelebihan jumlah dagangan disebut riba nasiah. Sedangkan ketika jumlah yang ditukar tidak serupa tetapi pertukaran berlangsung secara bersamaan, maka kelebihan yang diberikan dalam pertukaran disebut riba fadhl. Keduanya melanggar syariat Islam. ${ }^{19}$

\section{c. Jual beli mata uang}

Jual beli mata uang bagian dari riba. Menurut al-Ghazali perihal tersebut dilarang dalam praktik. Kemudian apabila jual beli mata uang diizinkan oleh pihak yang berwenang maka serupa dengan membebaskan pelaku melaksanakan praktik penimbunan uang yang berakibat pada kelengkapan uang dalam masyarakat. Akibat dari diperjualbelikan uang

17 Yang dimaksud riba di sini ialah riba nasi'ah. Menurut sebagian besar ulama bahwa riba nasi'ah itu selamanya haram, walupun tidak berlipat ganda. Riba itu ada dua macam: nasi'ah dan fadhl. Riba nasi'ah ialah pembayaran lebih yang disyaratkan oleh orang yang meminjamkan. Riba fadhl ialah penukaran suatu barang dengan barang yang sejenis, tetapi lebih banyak jumlahnya karena orang yang menukarkan mensyaratkan demikian, seperti penukaran emas dengan emas, padi dengan padi, dan sebagainya. Riba yang dimaksud dalam ayar ini riba nasi'ah yang berlipat ganda yang umum terjadi dalam masyarakat Arab zaman jahiliyah.

${ }^{18}$ Euis Amalia, Sejarah Pemikiran Ekonomi Islam, dari Masa Klasik Hingga Kontemporer, (Jakarta: Pustaka Asatrus, 2005), hlm. 129-130.

19 Yadi Janwari, Pemikiran Ekonomi Islam Dari Masa Rasulullah Hingga Masa Kontemporer, (Bandung: PT. Remaja Rosdakarya, 2016), hlm. 201. 
tersebut, maka uang hanya ada disekitar orang-orang kaya. Perbuatan tersebut sangat zalim untuk dilakukan.

Dengan demikian pandangan beliau penuh dengan semangat kemanusiaan yang menyeluruh serta etika bisnis Islami. Pemikiran keuangannya belum tertata rapi, maka diperlukan suatu konsep yang lebih baik lagi. Dengan demikian perlu adanya kerja keras dari para pakar setelahnya untuk menata kembali secara tahap demi tahap.

\section{d. Evolusi pasar}

Al-Ghazali menyajikan analisis terkait pentingnya dampak dari kegiatan ekonomi yang dikerjakan dengan sepenuh hati dan munculnya cara kerja pasar yang bersandarkan pada kekuatan permintaan dan penawaran sehingga menentukan harga pada keuntungan pasar tersebut. Tidak disangka beliau akhirnya menciptakan pokok-pokok yang sering disebut dengan semangat kapitalisme. Selain itu, pasar berkembang karena kekuatan alam, sebagai bagian dari suatu sistem alam dan sebagai bentuk motivasi manusia untuk secara sengaja mencukupi kebutuhan ekonomi.

Al-Ghazali menyatakan bahwasanya pasar adalah setengah dari keteraturan alami dan seluruh tentang evolusi terciptanya pasar. Beliau mengemukakan bahwa petani bisa saja bercocok tanam dengan alat pertanian yang bisa dikatakan tidak ada, sebagaimana dengan tukang besi dan tukang kayu juga hidup dengan lahan pertanian yang tidak ada. Akan tetapi secara alami, mereka saling membutuhkan satu sama lainnya. Dapat pula terjadi tukang kayu membutuhkan makanan, tetapi petani tidak membutuhkan alatalat tersebut atau sebaliknya. Persoalan ini memunculkan suatu masalah pada pasar. Oleh sebab itu, untuk memenuhi kebutuhannya mereka akan berpikir untuk menyiapkan tempat penyimpanan alat-alat dan benih hasilnya sehingga terbentuklah pasar. Petani, tukang kayu, dan tukang besi yang tidak bisa langsung melakukan tukar menukar juga tergelitik untuk pergi ke pasar. Apabila di pasar tidak melakukan transaksi tukar menukar, maka barang 
tersebut akan dijual dengan harga yang bisa dikatakan murah dan kemudian disimpan sebagai persediaan. Ketika pedagang menjual kembali maka akan menghasilkan keuntungan, perihal tersebut akan berlaku pada tiap barang dagangan. Dengan demikian permasalahan di atas bagian dari hukum alam yakni suatu hasrat yang muncul dari diri sendiri untuk saling memenuhi kebutuhan ekonomi ${ }^{20}$ Selanjutnya al-Ghazali mendeskripsikan praktik-praktik ekonomi diantaranya:

1) Praktik perdagangan antar wilayah

Menurut al-Ghazali praktik ini memiliki konsekuensi yang didapatkannya di berbagai wilayah lokal maupun global sehingga masyarakat yang bepergian akan memperoleh kebutuhan dan membawanya ke wilayah lain. Masalah ini akhirnya disalurkan kepada sebagian wilayah yang tidak mendapatkan makanan, yang pada gilirannya akan menimbulkan permasalahan pada alat transportasi. Tercipta pedagang regional tentu saja akan memberikan keuntungan kepada masyarakat. ${ }^{21}$

2) Teori permintaan dan penawaran

Teori ini mempromosikan bahwasanya ketika petani tidak mendapatkan pembeli maka akan menjualkan dagangannya pada harga yang lebih murah, dan bisa direndahkan dengan menaikkan barang di pasar. Selain itu, beliau juga mempromosikan elastisitas permintaan, mengenali permintaan produk makanan yang inelastic merupakan suatu kebutuhan awal. Oleh sebab itu, mesti dikurangi dalam mencari keuntungan yang lebih tinggi. Ketika ingin memperoleh laba yang lebih tinggi, maka semestinya pedagang menjual barang sekunder bukan barang primer. ${ }^{22}$

\footnotetext{
${ }^{20}$ Adiwarman Azwar Karim, Ekonomi Islam Suatu Kajian Kontemporer, (Jakarta: Gema Insani Press, 2001), hlm. 157.

${ }^{21}$ Ibid., hlm. 158.

${ }^{22}$ Heri Sudarsono, Konsep Ekonomi Makro Islam, (Yogyakarta: Ekonisia, 2004), hlm. 152.
} 
Hubungan antara harga dan keuntungan dibahas lebih luas lagi, meskipun para pedagang dipandang rendah untuk mencari keuntungan, beliau jelas mengakui motivasi dan sumber keuntungan diantaranya, keuntungan yang terkait dengan risiko dan ketidakpastian. Al-Ghazali mengungkapkan bahwa, "lihat, bagaimana Allah Swt. sudah mengenakan kepada mereka (pedagang) ketidaktahuan dan kebodohan karena mereka menanggung banyak kesulitan dalam mencari keuntungan dan mengambil risiko dan membahayakan kehidupan...". Selain itu, beliau juga menargetkan keuntungan yang tidak tinggi dan berlebihan. Beliau menyarankan jika pembeli menawarkan keuntungan tinggi maka pedagang mesti menahan diri dari keuntungan yang tinggi. Jadi dapat disimpulkan bahwasanya beliau tidak menetapkan batas keuntungan yang normal, misalnya sekitar 5 sampai 10\% dari harga barang yang dijual. ${ }^{23}$

Al-Ghazali meninggal di Teheran pada 505 H/1111 M. Sebelum meninggal beliau berpesan untuk dibawakan peti mati yang telah disediakan. Seolah-olah beliau mengusap peti dengan matanya, lalu berkata "apapun perintah Allah, saya siap melakukannya". Sambil meluruskan kakinya dan ketika orang melihat wajahnya Imam besar tersebut telah meninggal. ${ }^{24}$

Konsep pemikirannya terkait filsafat Islam maupun tasawuf tidak diragukan lagi. Beliau merupakan salah satu figur pemikir Islam yang sangat masyhur pada masanya. Beliau terkenal dalam dunia Islam maupun sejarah intelektual manusia. Pemikirannya bisa menerobos dan menjawab berbagai persoalan kemanusiaan sekarang ini. Di sekitaran umat Islam, beliau lebih dikenal sebagai tokoh filsafat dan tasawuf. Kenyataan ini tidak mengejutkan mengenang

\footnotetext{
${ }^{23}$ Yadi Janwari, Pemikiran Ekonomi..., hlm. 193.

${ }^{24}$ Jamil Ahmad, Seratus Muslim Terkemuka, (Jakarta: Pustaka Firdaus, 2000), hlm. 118.
} 
keberhasilan pemikirannya dengan melihat dari beberapa karya tulisnya. Dengan demikian, sebetulnya pemikiran beliau telah menyebar ke seluruh dunia baik dalam ilmu ekonomi maupun lainnya. Jadi dapat disimpulkan, al-Ghazali bukan hanya pandai masalah filsafat Islam dan tasawuf, tetapi juga pantai mengulas soal ekonomi, terutama masalah lembaga keuangan Islam. ${ }^{25}$

\section{Kesimpulan}

Dari penjelasan di atas bisa disimpulkan bahwa uang menurut alGhazali adalah benda yang berfungsi sebagai fasilitas untuk memperoleh barang lain. Benda tersebut dianggap tidak mempunyai nilai sebagai barang. Oleh sebab itu, beliau menyamakan uang sebagai cermin yang tidak memiliki warna sendiri tapi bisa menggambarkan semua jenis warna. Adapun pandangan keuangan al-Ghazali dalam perspektif sistem ekonomi Islam diantaranya larangan menimbun uang, artinya faktor utama pelarangan menimbun uang dikarenakan kehilangan fungsi yang melekat pada uang tersebut dan akan memberikan imbas negatif pada sistem ekonomi. Selain itu masalah riba dan jual beli mata uang, sebagaimana telah terkandung dalam firman Allah Swt. bahwa al-Ghazali mengharamkan hal tersebut. Terakhir evolusi pasar, menurut al-Ghazali sebagai bagian dari hukum alam atas segala sesuatu, yakni sebuah ekspresi berbagai hasrat yang timbul dari diri sendiri untuk saling memuaskan kebutuhan ekonomi.

\section{DAFTAR PUSTAKA}

Ahmad, J. (2000). Seratus Muslim Terkemuka. Jakarta: Pustaka Firdaus. Al-Qur'an Nur Qarim.

\footnotetext{
${ }^{25}$ Nur Chamid, Jejak Langkah..., hlm. 228-229.
} 
Amalia, E. (2005). Sejarah Pemikiran Ekonomi Islam, Dari Masa Klasik Hingga Kontemporer. Jakarta: Pustaka Asatrus.

Chamid, N. (2017). Jejak Langkah Sejarah Pemikiran Ekonomi Islam. Yogyakarta: Pustaka Pelajar.

Dimyati, A. (2008). Teori Keuangan Islam Rekontruksi Metodologis Terhadap Teori Kauangan Al-Ghazali. Yogyakarta: UII Press.

Haharap, S. A. R. (2019). Pemikiran Imam Al-Ghazali Tentang Fungsi Uang. Jurnal Laa Maisyir, 6(1), 1-15.

Jalaluddin. (2014). Konsep Uang Menurut Al-Ghazali. Asy-Syari'ah, 16(2), 16978.

Janwari, Y. (2016). Pemikiran Ekonomi Islam Dari Masa Rasulullah Hingga Masa Kontemporer. Bandung: PT. Remaja Rosdakarya.

Karim, A. A. (2004). Sejarah Pemikiran Ekonomi Islam. Jakarta: Rajawali Press.

- - - (2001). Ekonomi Islam: Suatu Kajian Ekonomi Makro. Jakarta: Karim Business Cansulting.

- - - (2001). Ekonomi Islam Suatu Kajian Kontemporer. Jakarta: Gema Insani Press.

Lestari, E. P. (2019). Ekonomi Moneter. Tangerang Selatan: Universitas Terbuka.

Mas'adi, G. A. (2002). Fiqh Muamalah Kontekstual. Jakarta: Rajawali Press.

Nasution, M. E, dkk. (2007). Pengenalan Eksklusif Islam. Jakarta: Kencana.

Rosia, R. (2018). Pemikiran Imam Al-Ghazali Tentang Uang. Jurnal Ilmiah Ekonomi Islam, 4(1), 14-27.

Sudarsono, H. (2004). Konsep Ekonomi Makro Islam. Yogyakarta: Ekonisia.

Sutopo. (2013). Pemikiran Imam Ghazali Tentang Ekonomi. Jurnal Ummul Qura, 32), 49-58. 
